UDK 631:636

\title{
TECHNOLOGICAL BASIS FOR PROCESS CONTROL OF PRODUCTION OF POULTRY PRODUCTION
}

\author{
V. I. Rebenko
}

National University of Life and Environmental Sciences of Ukraine. Ukraine.

Speciality of article: 133 - industry engineering.

Corresponding author: vicnb@ukr.net

Article history: Received - October 2019, Accepted - January 2020.

Bibl. 5, fig. 7, tabl. 2.

Abstract. The article summarizes the existing domestic, European and North American methodological requirements to test set of machines for poultry.

Characterized that the method of comparing the values of indicators in the subject of complex regulatory requirements and with relevant indicators for complex analog.

It is also established that the results of mathematical processing of measurement data used for comparison with the required values of technical specifications with the state acceptance tests (technical terms, if state periodic testing) for a decision on the conformity of the test complex technical requirements to technical specifications). There are two possible cases.

Also, for comparison of parameters obtained in the prototype testing of complex equipment and complex analog calculate the significance of differences in means.

Recommendations from the results of testing complex take on the basis of results of comparison of values of indicators of the test of complex equipment technical requirements for supply, zootechnical requirements and values for complex analog.

Key words: methodology, requirement, test, complex, machine for poultry.

\section{Introduction}

Poultry is a company specialized intensive poultry meat or egg directly.

Poultry feed derived from feed mills, while products produced evenly and rhythmically throughout the year.

Consider the following methods of cultivation and poultry, sexual, cellular and combined. In the floor keeping chickens kept pas poultry house floor with possible walking or not. In keeping chickens are outdoors and find their own food, herbs, insects, mineral supplements and more.

\section{Formulation of problem}

With this increased maintenance labor costs and limited concentration of livestock. Floor cultivation and breeding chickens is to use deep litter on the floor plan or mesh, good ventilation, optimal light conditions.

\section{Analysis of recent research results}

This increases the level of mechanization and automation of manufacturing processes, improves productivity, increases economic efficiency [1-5].

In keeping Cage chickens are placed in the cellular batteries consisting of several layers of cells [6, 7]. In each cell to accommodate 3-10 10-60 chickens or chicks [8-12]. Location chickens in small groups reduces stress in the formation of groups easier to observe them [13-15]. The relatively limited movement of chickens in cages leads to reduction of feed costs by $10-25 \%$ compared to the floor while keeping the same performance [16].

In keeping Cage increase the cost of the metal, but there is no need to litter in livestock increases 3-4 times per unit area [17-19].

Combined cultivation is that chickens to $1.5-2$ months of age are kept in cages with heated and then transferred them to the floor in keeping light areas that are not heated. This method is used in small poultry farms [20].

\section{Purpose of research}

Purpose of research - to reveal the main methodological requirements to test a set of machines for poultry farming.

\section{Results of research}

The process of egg production can consider poultry pas example of a complete cycle, from hatching eggs and meat to the diet of laying (Fig. 1).

The process of production of dietary egg starts in 1 shop breeder chickens, which provides full economy hatching eggs. Breeder located in housings 10 thousand heads, divided into 4-5 sections.

The shop incubation grade 3 eggs, disinfects and lay in bulk incubators for chickens according to a given rate 
of production. Streams 4 day-old chicks and 14 come from the workshops of incubation to 5 workshops

cultivation and breeding heifer replacement deha breeder 17.

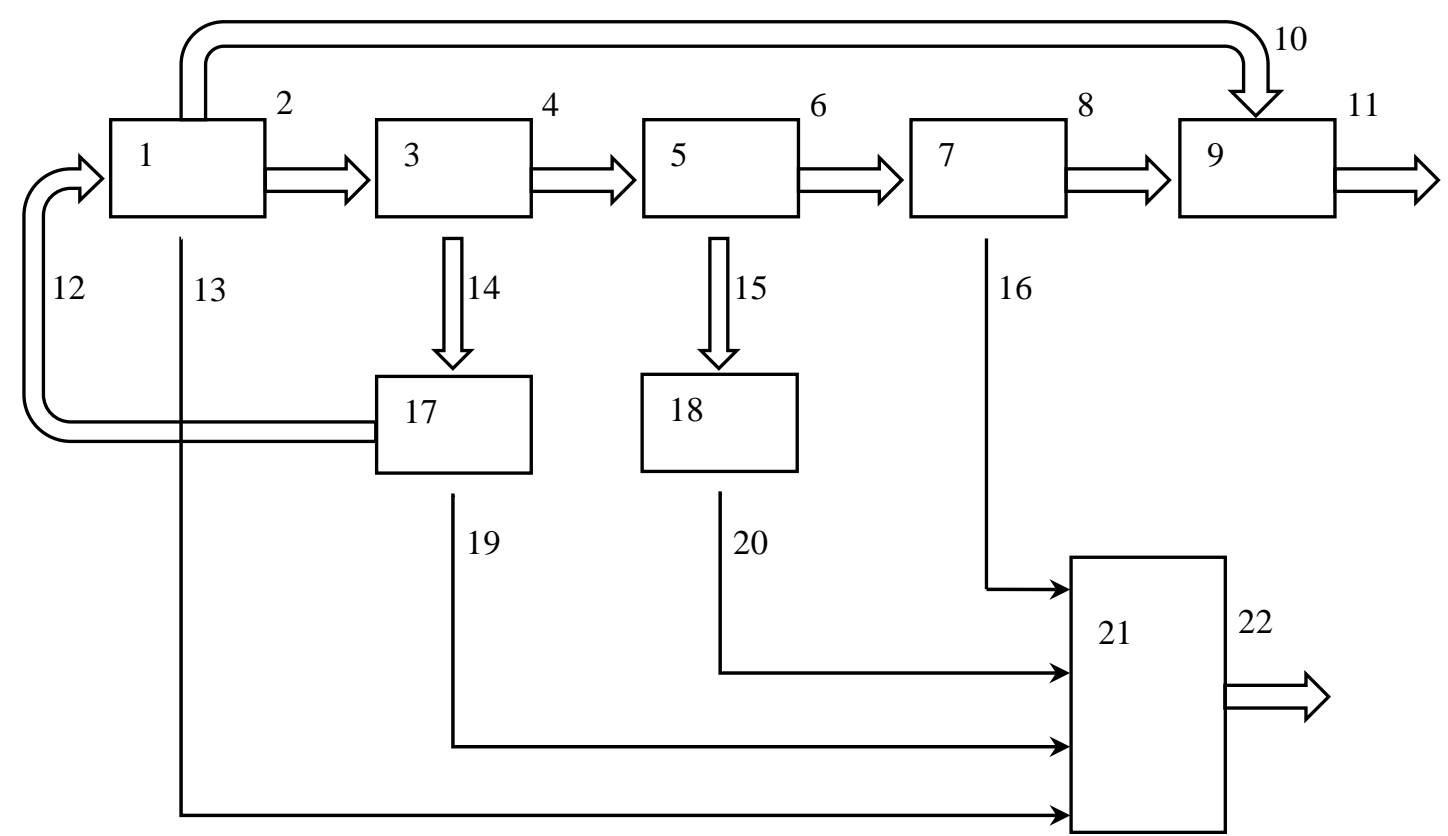

Fig. 1. Scheme of egg production process: 1 - shop of a parent herd, 2 - flow of incubation eggs, 3 - the shop of incubation, 4, 14 - streams of day-old chicks of industrial and pedigree herds, 5 - Growing shop, 6 - flow of young animals, 7 - industrial plant herd, 8, 10 - eggs flows, 9 - the shop for processing eggs, 11 - a stream of dietary eggs, 12 - the stream of repair young animals, 13, 16, 19, 20 - streams of discarded chickens in processing shops, 17 - Growing shop of young pigs of the parent flock, 15 - the flow of cockroaches, 18 - shop for fattening cocks, 21 - shop for processing chickens, 22 - sales of meat.

In plant breeding 5 day-old chicks are placed in a prepared disinfected the room and hold up to 140 days of age, depending on the method of keeping the floor, in cages or in combination. Then the stream top 12 cockerels and chickens parental forms sent to the breeder, and 6 stream of young plant growing - for the acquisition of industrial herd of 7 to 180 days of age, they are at heifer replacement. Rooster separated from the chickens in the daily or 30-day age and sent to the plant feeding 18 which are raised for meat subject to special diets. Stream 20 cockerels egg breeds rent for slaughter at the age of 60-90 days, when they reach mass 700-1200 g. Shop 7 industrial flock of chickens is the main element that gives dietary eggs. Chickens are kept in cages without cockerels. Stream 8 eggs collected from the hens of industrial herd and unsuitable for incubation breeder 10 goes to the processing plant Egg 9, where they are sorted, cleaned, packed and sent for implementation. Main production sector towards the egg - an egg diet (stream 11), and support - from chicken rejected $(13,19,20,16)$ chickens, roosters and nourished cockerels. The shop processing chickens spend 21 slaughter, processing carcasses, sorting, cooling and packaging for sale. Industrial aviary egg direction control is a complex subject with many uncertain ties.

Analysis of facility management is complicated by the fact that the processes in the poultry house, providing reception planned number of eggs do not occur during continuous operation, due to the presence of a large number of random disturbances. It should also be noted that the facility management total number of parameters to take into account when calculating the value management rather large. The composition of the flow of information can be found by expert assessments at three levels: engineer operator, foreman, chief specialist. To ensure the validity of the results of examination recommended rank correlation method which allows to determine the relationship between the findings of the panel. For poultry egg direction, the flow of information can be presented three types of parameters: technical, technology, technical and economic.

Prospects of automation in poultry. We were designed microprocessor control and process control in the poultry house. Fragments of the system implemented on the farm "Kyiv" and achieved high economic performance. The principle of operation of the system shown in the block diagram (Fig. 2). Process control by means of microcontrollers UYS2721. To improve the reliability of the control of the controller duplicated. When leaving one microcontroller system is blocked and process control equipment and takes over another controller. This signal is formed in damage to unit coordination and implementation of parallel processors. When a mismatch control signal signal appears the damage coming on both processors. The result is an automatic test both processors in which determine the one that failed. Allowing management of non-working CPU will then be available.

Management in this case, go to the processor, and display information through the block will be presented to the operator. Control signals from the processor enters the processor, and then depending on the type of control equipment enters the decryption unit, or digital-to-analog converter. 


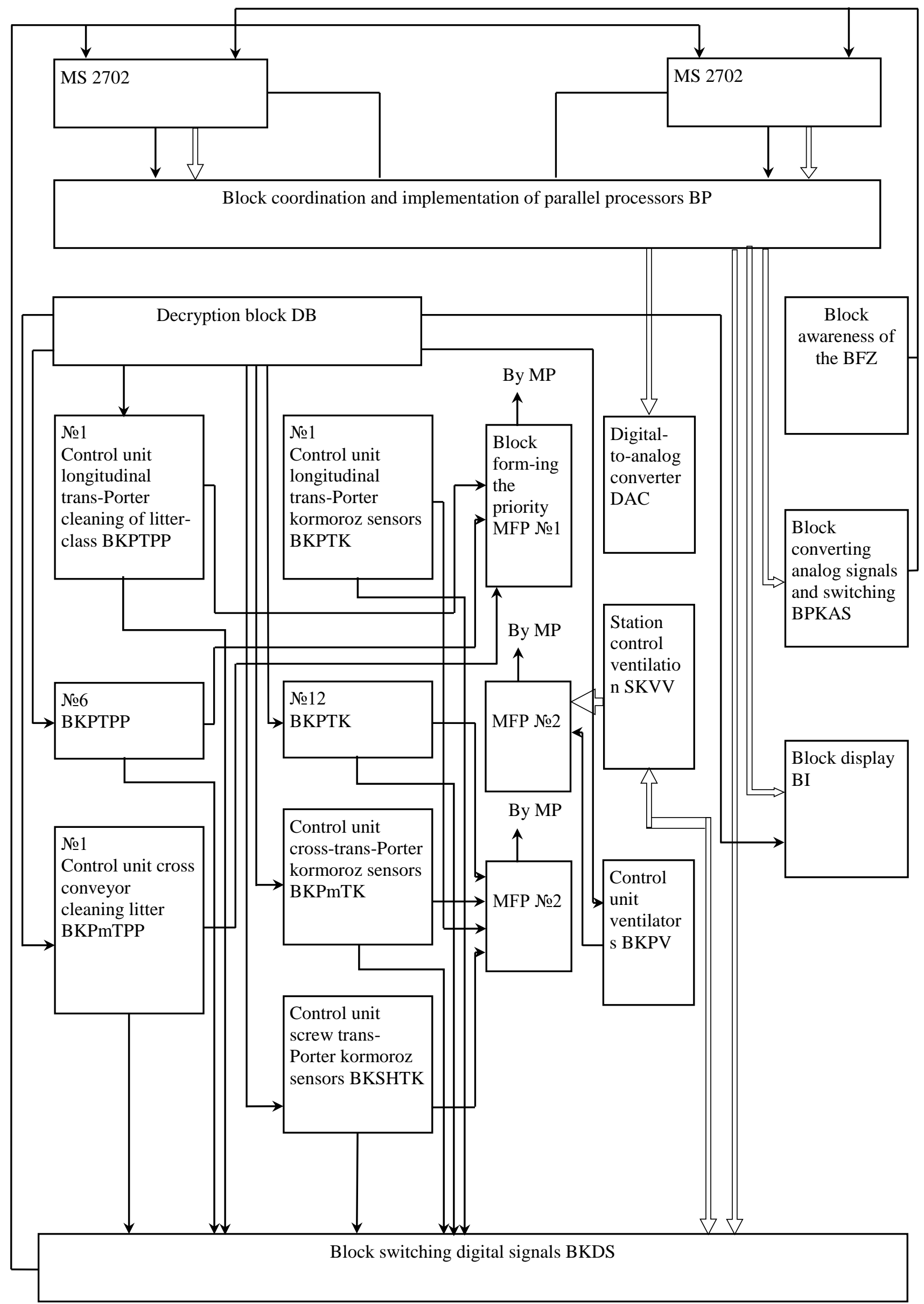

Fig. 2. Block diagram of the microprocessor system of monitoring and control of technological parameters in the poultry house. 


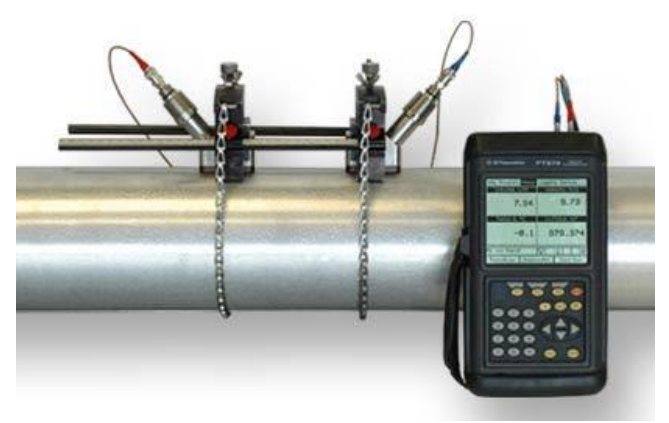

Fig. 3. Exterior of water

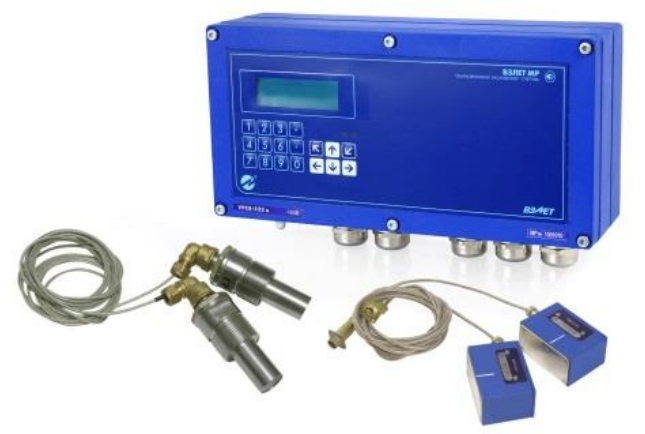

Fig. 4. Appearance feed flow type ECHO

To control the ventilation control signal in the form of eight parallel code enters the digital-to-analog converter where converted to an analog signal into a voltage and hits the boards ventilation. Managing other technological equipment decryption unit carried out by forming a control signal on it.

To control the process control unit used kormorozdachi longitudinal conveyor kormorozdachi LP ... L'12 control unit kormorozdachi cross conveyor, screw conveyor control unit kormorozdachi.

To control the process of removing litter from the block decryption signal supplied to the control unit longitudinal conveyor cleaning litter N1 ... N6, and the control unit transverse conveyor cleaning litter. Forced ventilation to control signal from the decryption unit enters the control unit ventilators. At malfunction in the control circuit electrical equipment, the failure of electric motors, with output operating modes beyond the nominal power in the formation of a priority signal which generates an interrupt signal entering the microprocessor.

Information about the rejection and the current values (on request) process parameters is formed and displayed in the block display.

Request current values of microclimate organization formed in the block query. Converting analog signals and input them into the microprocessor is in unit conversion and switching of analog signals.

In this system, such converters used (Fig. 3-5): temperature measuring - sensor type TSM, for humidity - sensor type DV-1K, to measure the cost of feed - flow type ECHO, for measuring water consumption - flow type IP.
IT farm designed and put into operation the first stage of the automatic control system integrated poultry farms (Fig. 6). Hierarchical it has two levels: the automated production management system, it includes automated dispatch control system and two automated process control systems - automated process control systems and automated power management process poultry. Through an automated system supervisory control is centralized temperature control in poultry houses - the system "Chestnut-T" - and centralized control and management regime in light housings "Chestnut-C".

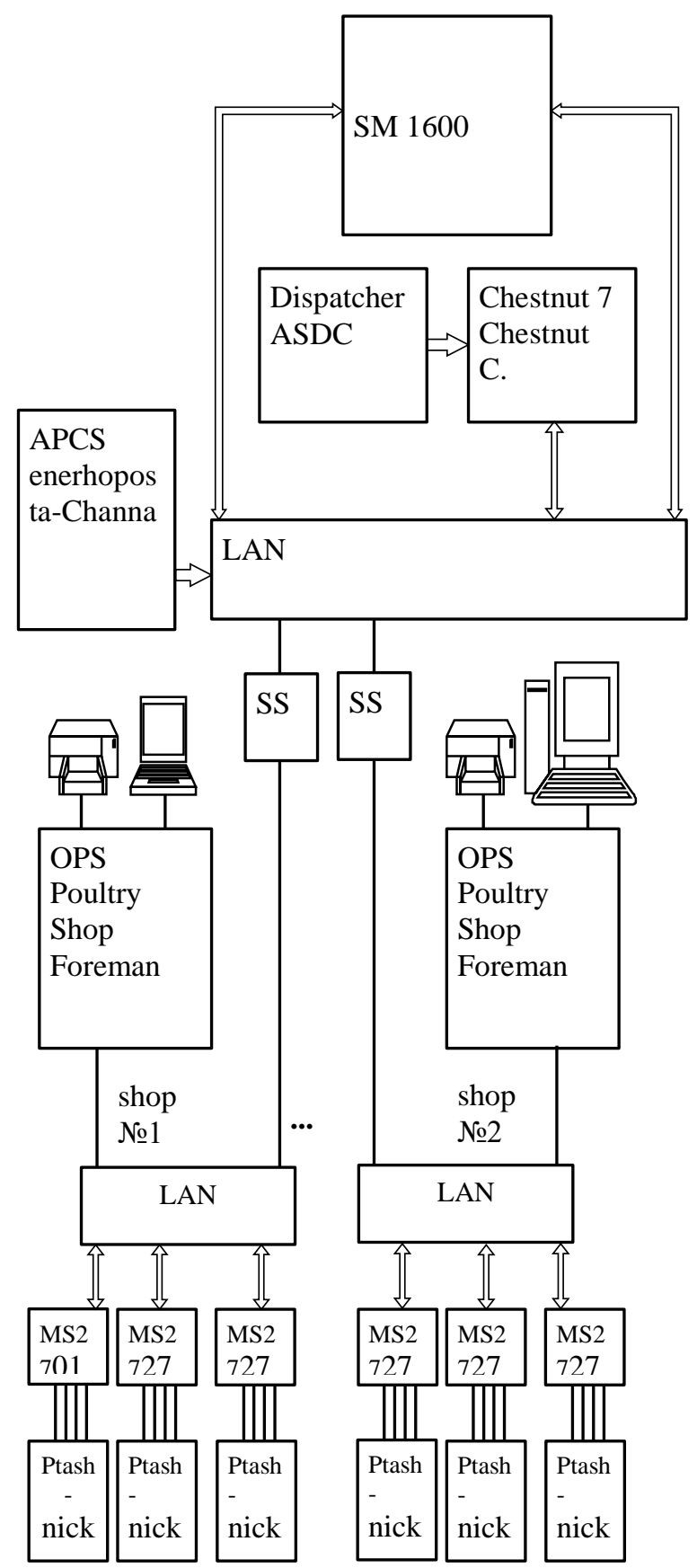

Fig. 6. Physical structure of the automated control system of technological processes at the poultry farm: ADCS - automated dispatch control system, $\mathrm{DC}$ - device of conjugation, $\mathrm{OpD}$ - operator's desk 

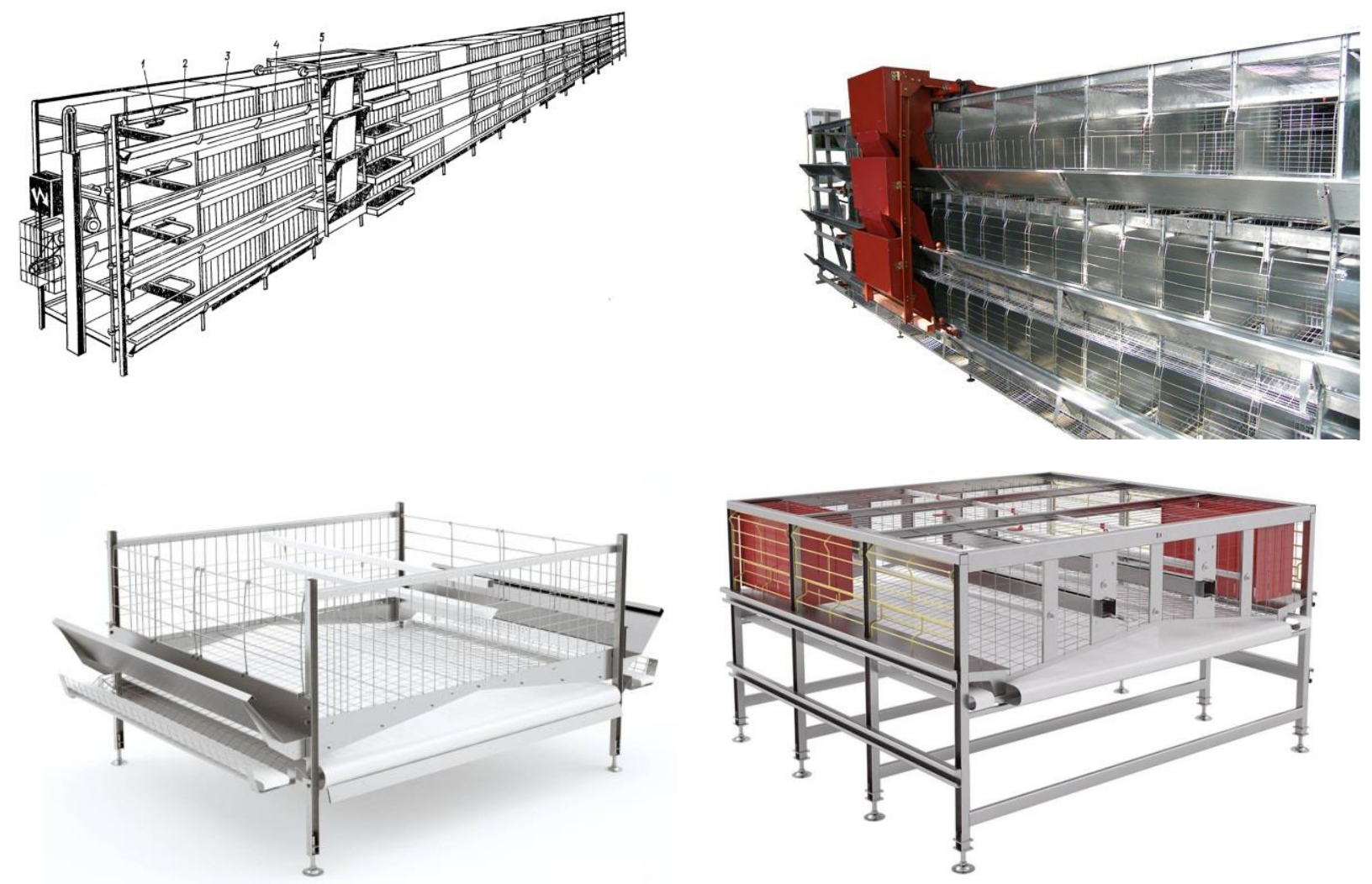

Fig. 7. Cell battery CBN for keeping chickens: 1 - drinking equipment, 2 - frame, 3 - cage, 4 - feeder, 5 - fodder breeder.

Table 1. Technical support this level is made on the basis of microcomputer CM 1810.

\begin{tabular}{|c|c|c|}
\hline \multicolumn{3}{|c|}{ Settings } \\
\hline technical & technological & feasibility \\
\hline $\begin{array}{l}\text { Failure: fan motor, Engine cellular } \\
\text { batteries. Control operability of } \\
\text { electrical equipment (motors } \\
\text { protection). Diagnosis and } \\
\text { forecasting of electric motors. } \\
\text { Diagnosis and management circles } \\
\text { of power networks (primary } \\
\text { measuring transducers). Self } \\
\text { control systems. Work tidal } \\
\text { ventilation and exhaust systems. } \\
\text { Work ventilators and water } \\
\text { heaters. }\end{array}$ & $\begin{array}{l}\text { Temperature: inner, external. The } \\
\text { concentration of } \mathrm{CO}_{2} \text {. Illumination } \\
\text { during daylight hours. The growth } \\
\text { of mass poultry. The velocity of the } \\
\text { air. The temperature of the coolant, } \\
\text { which is fed to the poultry house } \\
\text { heating system. Number of coolant } \\
\text { that passes through the circle } \\
\text { opposite the shop and each poultry } \\
\text { house (room) apart. The presence } \\
\text { and quantity of fodder in the } \\
\text { bunker. The concentration of NH3. }\end{array}$ & $\begin{array}{l}\text { Egg production, egg / h. Gross } \\
\text { production of eggs. Livestock } \\
\text { poultry. The cost of feed: g / head, } \\
\text { kg / } 1000 \text { pcs. eggs. Water } \\
\text { consumption: g / head, kg / } 1000 \\
\text { pcs. eggs. Culling chickens } \% \text { of } \\
\text { total stock, for slaughter, mortality. } \\
\text { Figure culling in relation to cross } \\
\text { biological characteristics. } \\
\text { Dynamics of egg weight. } \\
\text { Electricity consumption. Prediction. } \\
\text { Cost: USD. / } 1000 \text { pcs. eggs, UAH. } \\
/ 1 \text { kg of feed. }\end{array}$ \\
\hline
\end{tabular}

Table 2. Technological support this level is made on the basis of microcomputer CM 1810.

\begin{tabular}{|c|c|c|}
\hline \multicolumn{3}{|c|}{ Parameters } \\
\hline technical & technological & technical and economic \\
\hline $\begin{array}{l}\text { Fault: fan motors, cell battery } \\
\text { motors. Control of the electrical } \\
\text { capacity of electrical equipment } \\
\text { (protection of electric motors). } \\
\text { Diagnostics and forecasting of } \\
\text { electric motors. Diagnostics of } \\
\text { control circuits and power } \\
\text { networks (primary measuring } \\
\text { transducers). Self-diagnostics of } \\
\text { the control system. Work of the } \\
\text { tidal and exhaust ventilation } \\
\text { systems. Work of inflow } \\
\text { ventilation and water heaters. }\end{array}$ & $\begin{array}{l}\text { Temperature: internal, exterior } \mathrm{CO}_{2} \\
\text { concentration. Lighting during light } \\
\text { day. Bird mass increase. Speed of } \\
\text { air movement. Temperature of the } \\
\text { coolant, which is supplied to the } \\
\text { heating system of the poultry house. } \\
\text { The amount of coolant that passes } \\
\text { in the back of the shop and in each } \\
\text { poultry house (hall) separately. } \\
\text { Presence and quantity of mixed } \\
\text { fodders in the bunker. } \\
\text { Concentration } \mathrm{NH}_{3} \text {. }\end{array}$ & $\begin{array}{l}\text { Egg yolks, eggs per hour. Gross egg } \\
\text { production. The bird's head. Feed } \\
\text { expenditures: g / head, kg / } 1000 \\
\text { pcs eggs Water consumption: g / } \\
\text { head, kg / } 1000 \text { pcs eggs Chicken } \\
\text { excrement, \%, total number: for } \\
\text { slaughter, mortality. Chart plot in } \\
\text { relation to the biological } \\
\text { characteristics of the cross. The } \\
\text { evolution of the mass of eggs. } \\
\text { Electricity costs. Prediction of egg } \\
\text { production. Costs: UAH / } 1000 \text { pcs. } \\
\text { eggs, UAH / } 1 \text { kg of feed. }\end{array}$ \\
\hline
\end{tabular}




\section{Conclusions}

1. Automated process control system implemented at the poultry plant poultry, comprising 5 to 10 chicken houses. Technical support this level is made on the basis of microcomputer CM 1810. Composition of this information is presented in Table 1 and Table 2.

2. Directly in poultry houses are microcontrollers type MS2721 (MS2701) performing process control in the poultry house on a given program.

\section{References}

1. Fenenko, A. I. (2014). Biotechnical system of milk production. Theory and practice. Ed V. V. Adamchuk. Nizhyn. Publisher PE Lysenko. 192.

2. Shatsky, V. V. (2017). Modeling of biotechnical systems. Zaporizhia. Inter-M, 300.

3. Revenko, I. I., Revenko, Yu. I. (2017). Prospects and problems of processing of feed molotovie shredders. Nizhyn. Publisher PE Lysenko. 316.

4. Chmil, A. I. (2015). Energy efficiency and ecological safety of closed ecological and biotechnical systems in animal husbandry. Kiev. Komprint, 163.

5. Pogorely, L. V., Lutsenko, M. M. (2002). Biotechnical systems in animal husbandry. Kiev. Vintage, 344.

\section{Список літератури}

1. Фененко A. И. Биотехническая система производства молока. Теория и практика. Под ред. В. В. Адамчука. Нежин. Издатель ЧП Лысенко Н.М., 2014. 192c.

2. Шацкий В. В. Моделирование биотехнических систем. Запорожье. Интер-М, 2017. 300 с.

3. Ревенко І. І., Ревенко Ю. І. Перспективи i проблеми переробки кормів молотковими подрібнювачами. Ніжин. Видавець ПП Лисенко Н.М., 2017. $316 \mathrm{c}$.

4. Чміль A. I. Енергетична ефективність i екологічна безпека замкнутих еколого-біотехнічних систем в тваринництві: монографія. Київ. Компринт, 2015. $163 \mathrm{c}$.

5. Погорельй Л. В., Луценко М. M. Биотехнический системы в животноводстве. Киев. Урожай, 2002. 344 с.

\section{ТЕХНОЛОГІЧНІ ОСНОВИ УПРАВЛІННЯ ПРОЦЕСОМ ВИРОБНИЦТВА ПРОДУКЦІЇ ПТАХІВНИЦТВА \\ B. I. Ребенко}

Анотація. У статті узагальнено існуючі вітчизняні, європейські та північноамериканські методичні вимоги до випробувань комплексу машин для утримання птиці. Охарактеризовано, що методика порівняння значень показників по випробуваному комплексу до вимог нормативної документації і 3 відповідними показниками по комплексу-аналогу.
Також встановлено, що результати математичної обробки даних вимірювань використовують при порівнянні їх 3 необхідними величинами технічного завдання при державних приймальних випробуваннях (технічних умов при державних періодичних випробуваннях) для прийняття рішення про відповідність випробовується комплексу вимогам технічного завдання технічних умов). При цьому можливі два випадки. Також для порівняння показників, отриманих при випробуваннях дослідного зразка комплексу обладнання та комплексу-аналога підраховують значимість різниці середніх показників.

Рекомендації 3 результатів випробувань комплексу беруть на підставі результатів порівняння значень показників випробуваного комплексу обладнання вимогам технічних умов на поставку, зоотехническим вимогам і значеннями показників по комплексу-аналога.

Ключові слова: методика, вимога, випробування, комплекс, машина для утримання птиці.

\section{ТЕХНОЛОГИЧЕСКИЕ ОСНОВЫ УПРАВЛЕНИЯ ПРОЦЕССОМ ПРОИЗВОДСТВА ПРОДУКЦИИ ПТИЦЕВОДСТВА В. И. Ребенко}

Аннотация. В статье обобщены существующие отечественные, европейские и североамериканские методические требования к испытаниям комплекса машин для содержания птицы. Охарактеризовано, что методика сравнения значений показателей по испытуемому комплексу с требованиями нормативной документации и с соответствующими показателями по комплексу-аналогу.

Также установлено, что результаты математической обработки данных измерений используют при сравнении их с требуемыми величинами технического задания при государственных приемочных испытаниях (технических условий при государственных периодических испытаниях) для принятия решения о соответствии испытываемого комплекса требованиям технического задания технических условий). При этом возможны два случая. Также для сравнения показателей, полученных при испытаниях опытного образца комплекса оборудования и комплексааналога, подсчитывают значимость разницы средних показателей.

Рекомендации из результатов испытаний комплекса принимают на основании результатов сравнения значений показателей испытуемого комплекса оборудования требованиям технических условий на поставку, зоотехническим требованиям и значениями показателей по комплексу-аналога.

Ключевые слова: методика, требование, испытание, комплекс, машина для содержания птицы.

\section{I. Rebenko ORCID 0000-0003-0407-6435.}

